\title{
Hélisenne de Crenne, Les angoisses douloureuses qui procèdent d'amour
}

\section{Michele Mastroianni}

\section{Q OpenEdition}

1 Journals

\section{Edizione digitale}

URL: http://journals.openedition.org/studifrancesi/30058

DOI: $10.4000 /$ studifrancesi.30058

ISSN: 2427-5856

\section{Editore}

Rosenberg \& Sellier

\section{Edizione cartacea}

Data di pubblicazione: 1 avril 2006

Paginazione: 140

ISSN: 0039-2944

\section{Notizia bibliografica digitale}

Michele Mastroianni, «Hélisenne de Crenne, Les angoisses douloureuses qui procèdent d'amour», Studi Francesi [Online], 148 (XLX | I) | 2006, online dal 30 novembre 2015, consultato il 19 avril 2021. URL: http://journals.openedition.org/studifrancesi/30058; DOI: https://doi.org/10.4000/studifrancesi. 30058

Questo documento è stato generato automaticamente il 19 avril 2021.

\section{(c) (1)}

Studi Francesi è distribuita con Licenza Creative Commons Attribuzione - Non commerciale - Non opere derivate 4.0 Internazionale. 


\title{
Hélisenne de Crenne, Les angoisses douloureuses qui procèdent d'amour
}

\author{
Michele Mastroianni
}

\section{NOTIZIA}

HÉLISENNE DE CRENNE, Les angoisses douloureuses qui procèdent d'amour, édition par JEANPHILIPPE BEAULIEU, Saint-Étienne, Publications de l'Université de Saint-Étienne (Coll. «La cité des dames»), 2005, pp. 381.

1 A pochi anni di distanza dall'edizione critica ad opera di Christine de Buzon (Paris, Champion, 1997) compare, in un'agile collezione de poche consacrata alla letteratura femminile dell'Ancien Régime, una nuova edizione del fortunatissimo romanzo di Hélisenne de Crenne, vero best-seller del Rinascimento. Mentre Christine de Buzon per il suo lavoro si basava sulla prima edizione delle Angoisses del 1538, Jean-Philippe Beaulieu (che attende anche, con Diane Desrosiers-Bonin, alla pubblicazione del Songe di Hélisenne per i tipi di Champion) offre una versione del testo che non era mai stata oggetto di edizione né parziale né completa, quella contenuta nelle CEuvres de ma dame Hélisenne del 1543 (Paris, Charles Langelier), ultimo stadio del testo prima della revisione proposta da Claude Colet nell'edizione del 1551. Gli errori dell'edizione Langelier sono corretti alla luce dell'edizione del 1539 (Lyon, Denis de Harsy) e di quella del 1541 (Paris, Pierre Sergent). Appare quindi evidente l'interesse del lavoro di Beaulieu, concernente un'opera su cui si intensificano oggi gli interventi degli studiosi. Utile il breve saggio introduttivo (pp. 7-26). Accurato il glossario. 